\title{
Toxicological and Forensic Evaluation of Injury Pattern and Mortality in Marijuana Smoking Drivers and Non-Drugged Drivers: a Comparative Study
}

\author{
Marwa M. Shahin and Arwa A. Abuelfadl ${ }^{1}$
}

${ }^{1}$ Department of Forensic Medicine and Clinical Toxicology, Faculty of Medicine, Tanta University, Tanta, Egypt

\begin{abstract}
Cannabis is the most widely consumed illicit substance worldwide. Acute cannabis intoxication can produce impairment of driving skills. Driving under the influence of cannabis is a growing global public health concern. The present study aimed to compare injury pattern and subsequent clinical outcome that occur in both marijuana smoking drivers and non-drugged drivers among motor car accident victims admitted to Tanta University Emergency Hospital.

This study was carried out on 38 drivers of both sexes admitted to emergency department, Tanta University Emergency Hospital for recent road traffic injury. They were divided into two groups; 22 nondrugged drivers (group I) and 16 marijuana smoking drivers (group II).A complete clinical assessment of each patient was done. Urine sample was obtained from each patient and was subjected to rapid qualitative screening. Samples that revealed positive marijuana were subjected to Axsym ${ }^{\circledR}$ Abbott Cannabinoids assay to detect cannabinoids level.

The results of the current study revealed significant statistical difference between non-drugged drivers and marijuana smoking drivers in mortality, Injury Severity Score (ISS) and Revised Trauma Score (RTS). On the other hand, injury pattern did not register any significant statistical difference between non-drugged drivers and marijuana smoking drivers. Furthermore, There was no significant correlation between urine cannabis level and both RTS and ISS. Additionally, there was no significance difference in urine cannabis level between died and alive patients.

Future comparable researches on larger scale are required with detection of accurate cannabis blood level. Such data will help both prevention and better management of marijuana smoking drivers, with subsequent decrease in morbidity and mortality.
\end{abstract}

\section{Introduction}

$\mathrm{C}$ annabis is 2015).Acute psychological effects of cannabinoids include euphoria, dysphoria, sedation and altered perception (Ashton, 1999).The intensity of euphoria/dysphoria varies according to the dose, administration route, expectations of effects and the cannabis smoker's environment and personality (Ronen et al., 2008).

Acute cannabis intoxication produces doserelated impairment in cognitive and psychomotor functioning and it can produce risk-taking behavior that can impair driving skills(Lane et al., 2005 and Ramaekers et al., 2006).Cannabis has been reported by the American National Roadside Survey as the most common illicit drug quantified in drivers' blood or oral fluid (Compton \&Berning, 2009andLacey et al., 2009).

In consequence, driving under the influence of cannabis is a growing global public health concern. Road traffic injuries represent another global public health concern that account for more than 1.2 million lives were lost annually across the globe. This loss is accompanied by almost 50 million injuries which contribute to the global disability burden. Most of this burden is born by the low and middle income countries of the world. Human behavior factors, vehicle factors, and road factors contribute to the causation of road traffic crushes (Sharma, 2008and Mir et al., 2012). 
Considering human behavior factors, after alcohol (ethanol), cannabis is the most frequent substance detected in victims in fatal road traffic collisions (RTCs) in the United States, Australia, the UK and many European countries (Drummer et al., 2012 ; Hartman \&Huestis, 2013).Despite the fact that cannabis use is associated with significant risk of motor vehicle crashes (Asbridge et al., 2012 ; Li et al., 2012), more than half of those who used cannabis and drove did not believe cannabis use increased safety risks (Swift et al., 2010). In fact, cannabis is often viewed as the "least risky illicit drug" and fewer consequences are expected by cannabis users (Arterberry et al., 2012).

In Egypt, more than 20 thousands accidents occur annually, the majority of which were by drug influenced truck drivers (Obada, 2009).Impaired drivers risk injuring themselves and others, often without realizing that ingesting certain medications can lead to greater impairment. Understanding the contribution of marijuana smoking to adverse consequences, such as serious injury or trauma resulting from road traffic accidents is of great concern to the clinicians responsible for counseling such patients(Zavala \& French, 2003).

However, there has been a relative dearth of studies conducted to illuminate the problem of drugged driving particularly in Egypt. Hence, the present study was conducted to compare injuries pattern and subsequent clinical outcome that occur in both marijuana smoking drivers and non-drugged drivers due to motor car accidents in Tanta University Emergency Hospital.

\section{Patients and methods}

This prospective comparative cross sectional study was conducted in Tanta University Emergency Hospital, Tanta, Egypt. It was approved by the Research Ethical Committee, Faculty of Medicine, Tanta University. A written informed consent was obtained from each patient or his relatives (if the patient is comatose). All individual information was securely protected by giving a code number for everyone and was available to investigators only. All the data were analyzed anonymously.

\section{Eligibility criteria}

Over a period of six months (March 2015toSeptember 2015), drivers of both sexes admitted to emergency department, Tanta University Emergency Hospital, whether admitted to intensive care unit or who became candidates for surgical interference for recent road traffic injury were included in this study. Likewise, drivers who are presented either for the first time or with a history of repeated injury were included. Drivers were divided into two groups ; non-drugged drivers (group I) and marijuana smoking drivers(group II).The latter was furtherly divided into two subgroups; died patients and survived patients.

Exclusion criteria include drivers who are returning for check-ups were excluded. Moreover, drivers who registered abused substances other than cannabis or more than one substance in urine were excluded. Patients who died either at the scene or en route to the hospital were similarly excluded from the study. In the same way, patients with history of current diseases that may lead to road traffic accident (epilepsy, diabetes mellitus, coronary heart disease, hypertension, liver diseases and problems of binocular vision) were excluded.

A standard sheet was conducted to record complete clinical assessment of each patient. The following data were recorded for each patient:

- Personal history: it includes name, age, gender, residence, marital status, special habits (first time or repeated use), educational level, occupation and socioeconomic status.

- Past history: it includes history of operations, chronic systemic illness (diabetes, hypertension, renal, liver or blood disease or others),types of abused substances before injury, and history of previous admissions for traumatic injury.

- Pre-hospital care: if any intervention occurred before reaching the hospital.

- Clinical Examination: Vital signs, neurological, respiratory system, cardiovascular system, GIT, urinary system and orthopedic examination were done for every patient.

- Injury Examination: Assessment of all injuries, recording and sorting according to site into: Head and neck injuries, abdomen and pelvic contents injuries, bony pelvis and limbs injuries, chest injuries, face injuries and body surface wounds.

- Injury Severity Score (ISS): is an index of anatomical injury was calculated from the Abbreviated Injury Scale (AIS) as shown in table (I)(Nayeem et al., 1992 and Van Natta \& Morris, 2000). An Injury Severity Score (ISS) more than 15 was considered to represent severe injury (Nayeem et al., 1992).

- Revised Trauma Score (RTS): is based on scales of three main systems likely to show physiological response to injury; the respiratory system, the cardiovascular system, and the central nervous system. This scale in crude form runs from 0 to 12 (Table II). For the purposes of medical audit, a weighted form is used in which the crude coding values are corrected with weighting factors. The coded value derived from the Glasgow Coma Scale is multiplied by 0.9368 , the code for systolic blood pressure by 0.7326 and the code for the respiratory rate by 0.2908 . After these weights are used, the Revised Trauma Score has a corrected value between 0 and 8, which correlates very well with survival probability (Nayeem et al., 1992 and Van Natta \& Morris, 2000). 


\begin{tabular}{|lc|}
\hline \multicolumn{2}{|l|}{ Table (1): The Abbreviated Injury Score (AIS) } \\
Score & Example \\
1 Minor & Wrist sprain \\
2 Moderate & Closed, undisplaced \\
& tibial fracture \\
3 Serious & Fractured femur \\
4 Severe & Ruptured spleen \\
5 Critical & Extradural haemorrhage \\
6 Fatal & Laceration of brain stem \\
& \\
Injury Severity Score & \\
A. Score every injury using the Abbreviated Injury Scale. \\
B. Identify the highest AIS in each of the following six \\
areas: & \\
Head and neck & \\
Abdomen and pelvic contents & \\
Bony pelvis and limbs & \\
Face & \\
Chest & \\
Body surface & \\
C. Add together the squares of the three highest area \\
scores
\end{tabular}

According to Nayeem et al. (1992)

\begin{tabular}{|c|c|c|c|}
\hline \multicolumn{4}{|c|}{$\begin{array}{l}\text { Table (2): Values for Revised Trauma Score (crude } \\
\text { form) }\end{array}$} \\
\hline $\begin{array}{l}\text { Glasgow } \\
\text { Coma Scale }\end{array}$ & $\begin{array}{l}\text { Systolic } \\
\text { blood } \\
\text { pressure }\end{array}$ & $\begin{array}{l}\text { Respiratory } \\
\text { rate }\end{array}$ & $\begin{array}{l}\text { Coded } \\
\text { value }\end{array}$ \\
\hline $13-15$ & $>89$ & $10-29$ & 4 \\
\hline $9-12$ & $76-89$ & $>29$ & 3 \\
\hline $6-8$ & $50-75$ & $6-9$ & 2 \\
\hline $4-5$ & $1-49$ & $1-5$ & 1 \\
\hline 3 & 0 & 0 & 0 \\
\hline
\end{tabular}

According to Nayeem et al.( 1992)

\section{Sampling methods}

Ten $\mathrm{ml}$ urine was obtained from each patient at the time of admission and before receiving any treatment. Any turbid samples or those containing blood were excluded. Catheterization was done if the patient was unable to void urine or comatose. Each sample was collected in a clean dry and labeled container with code number and sample date. Each sample was subjected to rapid qualitative screening by $\mathrm{ACON}^{\circledR} \mathrm{DOA}^{\mathrm{TM}}$ kits(multi-drug panel Enzyme Immunoassay kits) for qualitative screening analysis of cannabinoids, opiates, benzodiazepines, barbiturates and amphetamines(Joseph \& Ronald, 2006). Non-drugged drivers are non-drugged by any of these drugs. Samples that revealed positive drugs other than cannabis were excluded. Then, urine samples were subjected to Axsym ${ }^{\circledR}$ Abbott Cannabinoids assay (a semi-quantitative reagent system). This step was done to detect the cannabinoids level in positive urine samples with cut off value $50 \mathrm{ng} / \mathrm{ml}$ (Joseph \& Ronald, 2006).

\section{Statistical analysis of data}

Data were collected and entered to the computer using SPSS program for statistical analysis (version 20). Data were entered as numerical or categorical, as appropriate. Kolmogorov-Smirnov test (KS) revealed significance in the distribution of variables (i.e. not-normally distributed data), so, non-parametric statistics was carried out.

- Exploration of the data: This yielded complete descriptive statistics including the minimum and maximum, range, mean, standard deviation and median for each variable.

- Comparisons were carried out between the two studied subgroups using Mann-Whitney test.

- Chi- square test and fisher exact test were used to measure association between qualitative variables. Monte Carlo correction and Fisher Exact correction were carried out when indicated (expected cells less than 5) (Field, 2006).

\section{Results \\ Study population characteristics}

During the study period(March 2015 to September 2015), a total of 53 drivers of both sexes were admitted to Tanta University Emergency Hospital for road traffic injury. There were 22(41.51\%) non-drugged drivers; they comprise group I, while, marijuana smoking drivers (group II) included 16 (30.19\%) victims. Drivers who were either multiple-drugged drivers or drugged with drugs other than marijuana were excluded.

Table (3) showed that, age in the total study population ranged between 18 and 63 years (30.31 \pm 9.937$)$. Males represented 32 patients $(84.2 \%)$, while females represented 6 patients (15.8\%). No significant statistical difference in both age and gender distribution could be detected between non-drugged drivers and marijuana smoking drivers $(\mathrm{p}=0.693$ and $\mathrm{p}=0.370$ respectively).

Vital signs and Glasgow Coma Scale of the total study population are shown in table (4). Comparison between non-drugged drivers and marijuana smoking drivers did not demonstrate any statistical significant association in either vital signs or Glasgow Coma Scale ( $\mathrm{p}$ value $\geq 0.05$ )

\section{Injury pattern of non-drugged drivers and marijuana smoking drivers}

The injury pattern, mortality, Injury Severity Score (ISS) and Revised Trauma Score (RTS)of the total study population are presented in table (5). It revealed significant statistical difference between non-drugged drivers and marijuana smoking drivers in mortality, Injury Severity Score (ISS) and Revised Trauma Score (RTS), where $\mathrm{p}$ values were $0.043^{*}, 0.035^{*}$ and 
$0.040 *$ respectively. On the other hand, injury pattern did not register any significant statistical difference between non-drugged drivers and marijuana smoking drivers( $\mathrm{p}$ value $\geq 0.05$ ).

Non-drugged drivers revealed extra-dural hemorrhage with black eye in three drivers. Out of them, only one driver showed depressed fracture with subDural hemorrhage. All of the head and neck injured nondrugged drivers registered sever ISS $(29,29,38)$. Sciatic nerve injury and retroperitoneal hematoma occurred in one non-drugged driver. Dislocation and different fractures in the bonny pelvis and limbs were detected in fourteen non-drugged drivers. Out of them, only two drivers registered sever ISS $(20,38)$, they were presented by amputation of parts of fingers and open fracture tibia. Facial affection in non-drugged drivers was limited to fracture body of mandible and facial laceration in two cases. Involvement of the chest was restricted to fracture clavicle and fracture rib in two non-drugged drivers. All cases of group I exhibited various types of injuries on the body surface; abrasions, bruises, contusions, contused, lacerated and cut wounds.

Marijuana smoking drivers showed depressed comminuted Fracture with extradural hemorrhage in three patients, all of them recorded sever ISS (38, 29, 38). Fracture with extradural hemorrhage was noticed in two marijuana smoking drivers who were as well in the sever ISS $(42,38)$. Depressed fracture and black eye were observed in two cases, one of them suffered extraDural and sub-Dural hemorrhage. Both of them recorded sever ISS $(45,29)$. Pelvi-abdominal injuries were in the form of rupture spleen and intraperitoneal hemorrhage which occurred in two sever ISS marijuana smoking drivers $(42,20)$. Fracture pelvis and pelvic hematoma were noted in one marijuana smoking driver whom ISS was sever (20). Marijuana smoking drivers registered two cases of simple fracture femur and one case of simple fracture tibia, only one of them was sever ISS (38). Open fractures in radius, patella, tibia and fibula were seen in three different marijuana smoking drivers, out of them two cases recorded sever ISS $(38,38)$. One marijuana smoking driver suffered fracture humerus with shoulder dislocation. Chest involvement was represented by two cases of fracture ribs one of them was open (sever ISS 45) in marijuana smoking drivers. All cases of group II exhibited various types of injuries on the body surface; abrasions, bruises, contusions, contused and cut wounds.

The previously mentioned injuries in marijuana smoking drivers and non-drugged drivers are illustrated according to type of bony injuries and injury severity score in tables (6 and 7) respectively.

Table (8) revealed the cause of death in both marijuana smoking drivers and non-drugged drivers. Two patients of non-drugged drivers have died due to severe head injury and multiple fracture ribs with flail chest and lung injury. On the other hand, six of marijuana smoking drivers have died due to severe head injury and Heamorrhagic shock.

\section{Association between marijuana urine level and both ISS, RTS and mortality}

Cannabis urine level ranged between 52 and $1418.12 \mathrm{ng} / \mathrm{ml}$. There was no significant correlation between cannabis urine level and $\operatorname{RTS}(\tau=0.152$, $\mathrm{p}=0.445)$ or between cannabis urine level and ISS $(\tau=0.207, \quad \mathrm{p}=0.275)$. Additionally, there was no significance difference in cannabis urine level between died $(n=6)$ and survived $(n=10)$ patients $(Z M W=1.302$, $\mathrm{p}=0.193)$ as shown in tables $(9 \& 10)$.

Table (3): Chi-Squared test with Fisher exact correction analysis of demographic data of marijuana smoking drivers $(n=16)$ and non-drugged drivers $(n=22)$

\begin{tabular}{|l|c|c|c|}
\hline \multicolumn{1}{|c|}{$\begin{array}{c}\text { Vriable } \\
\text { Age in years }\end{array}$} & $\begin{array}{c}\text { Marijuana smoking drivers } \\
(\mathbf{n = 1 6 )}\end{array}$ & $\begin{array}{c}\text { Non-drugged drivers } \\
(\mathbf{n = 2 2})\end{array}$ \\
\hline \multicolumn{1}{|c|}{$\begin{array}{c}\text { Test of } \\
\text { significance } \\
(\mathbf{p} \text { value })\end{array}$} \\
Minimum-Maximum & $18.00-63.00$ & $18.00-40.00$ & $18.00-63.00$ \\
Mean \pm Std. Deviation & $30.31 \pm 9.937$ & $28.87 \pm 7.338$ & $31.36 \pm 11.524$ \\
Median & 30.00 & 29.50 & 30.00 \\
\hline Gender Male & $32(84.2 \%)$ & $15(93.8 \%)$ & $17(77.3 \%)$ \\
Female & $6(15.8 \%)$ & $1(6.3 \%)$ & $5(22.7 \%)$ \\
\hline
\end{tabular}

FE: Fisher Exact $p$ value, $P^{*} \leq 0.05=$ significant, $P>0.05=$ non significant 
Table (4): Mann-Whitney $U$ test and Chi-Squared test with Monte Carlo correction analysis of initial vital data of marijuana smoking drivers $(n=16)$ and non-drugged drivers $(n=22)$

\begin{tabular}{|c|c|c|c|c|}
\hline Variable & $\begin{array}{l}\text { total study sample } \\
\qquad(\mathrm{n}=38)\end{array}$ & $\begin{array}{c}\text { Marijuana } \\
\text { smoking drivers } \\
(n=16)\end{array}$ & $\begin{array}{l}\text { Non-drugged } \\
\text { drivers }(n=22)\end{array}$ & $\begin{array}{c}\text { Test of } \\
\text { significance } \\
\text { (p value) }\end{array}$ \\
\hline $\begin{array}{l}\quad \text { Heart rate (per minute) } \\
\text { Minimum-Maximum } \\
\text { Mean } \pm \text { Std. Deviation } \\
\text { Median }\end{array}$ & $\begin{array}{c}73.00-130.00 \\
93.92 \pm 15.676 \\
88.00 \\
\end{array}$ & $\begin{array}{c}73.00-123.00 \\
92.68 \pm 14.781 \\
88.00 \\
\end{array}$ & $\begin{array}{c}77.00-130.00 \\
94.81 \pm 16.580 \\
88.00 \\
\end{array}$ & $\begin{array}{l}Z=0.313 \\
p=0.759\end{array}$ \\
\hline $\begin{array}{l}\text { Diastolic blood pressure (mmHg) } \\
\text { Minimum-Maximum } \\
\text { Mean } \pm \text { Std. Deviation } \\
\text { Median }\end{array}$ & $\begin{array}{c}40.00-90.00 \\
68.94 \pm 11.098 \\
70.00 \\
\end{array}$ & $\begin{array}{c}50.00-90.00 \\
68.75 \pm 10.878 \\
70.00\end{array}$ & $\begin{array}{c}40.00-90.00 \\
69.09 \pm 11.509 \\
70.00\end{array}$ & $\begin{array}{l}Z=0.433 \\
p=0.693\end{array}$ \\
\hline $\begin{array}{ll} & \text { Glasgow Coma Scale } \\
3-8 & \\
9-12 & \\
13-15 & \\
\end{array}$ & $\begin{array}{c}7(18.4 \%) \\
5(13.2 \%) \\
26(68.4 \%)\end{array}$ & $\begin{array}{c}3(13.6 \%) \\
1(4.5 \%) \\
18(81.8 \%)\end{array}$ & $\begin{array}{l}4(25.0 \%) \\
4(25.0 \%) \\
8(50.0 \%)\end{array}$ & $\begin{array}{c}\mathrm{X}^{2}=4.965 \\
\mathrm{p}_{(\mathrm{MC})}=0.087\end{array}$ \\
\hline
\end{tabular}

MC: Monte Carlo correction, $P^{*} \leq 0.05=$ significant, $P>0.05=$ non significant

Table (5): Mann-Whitney $U$ test and Chi-Squared test with Fisher exact correction analysis of injury pattern in marijuana smoking drivers $(n=16)$ and non-drugged drivers $(n=22)$

\begin{tabular}{|c|c|c|c|c|}
\hline Variable & $\begin{array}{c}\text { total study } \\
\text { sample }(n=38)\end{array}$ & $\begin{array}{c}\text { Marijuana } \\
\text { smoking drivers } \\
(\mathrm{n}=16)\end{array}$ & $\begin{array}{l}\text { Non-drugged } \\
\text { drivers } \\
(\mathbf{n}=\mathbf{2 2})\end{array}$ & $\begin{array}{c}\text { Test of significance } \\
\text { (p value) }\end{array}$ \\
\hline $\begin{array}{l}\text { Injuries } \\
\text { Head injury } \\
\text { Abdomen \& pelvic contents } \\
\text { Bony pelvis \& limbs } \\
\text { Chest } \\
\text { Face } \\
\text { Body surface }\end{array}$ & $\begin{array}{c}10(26.3 \%) \\
3(7.9 \%) \\
22(57.9 \%) \\
4(10.5 \%) \\
2(5.3 \%) \\
38(100 \%)\end{array}$ & $\begin{array}{c}7(43.8 \%) \\
2(12.5 \%) \\
8(50.0 \%) \\
2(12.5 \%) \\
0(0.0 \%) \\
16(100 \%)\end{array}$ & $\begin{array}{c}3(13.6 \%) \\
1(4.5 \%) \\
14(63.6 \%) \\
2(9.1 \%) \\
2(9.1 \%) \\
22(100 \%)\end{array}$ & $\begin{array}{c}\mathrm{X}^{2}=4.332, \mathrm{p}_{(\mathrm{FE})}=0.062 \\
\mathrm{X}^{2}=0.806, \mathrm{p}_{(\mathrm{FE})}=0.562 \\
\mathrm{X}^{2}=0.707, \mathrm{p}_{(\mathrm{FE})}=0.401 \\
\mathrm{X}^{2}=0.114, \mathrm{p}_{(\mathrm{FE})}=0.735 \\
\mathrm{X}^{2}=1.535, \mathrm{p}_{(\mathrm{FE})}=0.215 \\
\mathrm{NA}\end{array}$ \\
\hline Mortality & $8(26.3 \%)$ & $6(37.5 \%)$ & $2(9.1 \%)$ & $\begin{aligned} \mathrm{X}^{2} & =4.498 \\
\mathrm{p}_{(\mathrm{FE})} & =0.043^{*}\end{aligned}$ \\
\hline $\begin{array}{l}\quad \text { Injury Severity Score(ISS) } \\
\text { Minimum-Maximum } \\
\text { Mean } \pm \text { Std. Deviation } \\
\text { Median }\end{array}$ & $\begin{array}{c}1.00-45.00 \\
16.68 \pm 12.702 \\
13.00\end{array}$ & $\begin{array}{c}1.00-45.00 \\
22.37 \pm 14.700 \\
20.00 \\
\end{array}$ & $\begin{array}{c}2.00-38.00 \\
12.54 \pm 9.343 \\
10.00\end{array}$ & $\begin{array}{l}\mathrm{Z}=2.101 \\
\mathrm{p}=0.035^{*}\end{array}$ \\
\hline $\begin{array}{l}\text { Revised Trauma Score (RTS) } \\
\text { Minimum-Maximum } \\
\text { Mean } \pm \text { Std. Deviation } \\
\text { Median }\end{array}$ & $\begin{array}{c}3.57-7.84 \\
7.10 \pm 1.281 \\
7.84\end{array}$ & $\begin{array}{c}4.30-7.84 \\
6.82 \pm 1.289 \\
7.22\end{array}$ & $\begin{array}{c}3.57-7.84 \\
7.31 \pm 1.263 \\
7.84\end{array}$ & $\begin{array}{l}\mathrm{Z}=2.049 \\
\mathrm{p}=0.040 *\end{array}$ \\
\hline
\end{tabular}

FE: Fisher Exact $p$ value $P^{*} \leq 0.05=$ significant, $P>0.05=$ non significant 
Table (6): Type and percentage of bony injuries in marijuana smoking drivers and non-drugged drivers

\begin{tabular}{|c|c|c|c|c|c|c|}
\hline \multirow[t]{2}{*}{ Type } & \multicolumn{2}{|c|}{ Marijuana smoking drivers $(n=16)$} & \multicolumn{2}{|c|}{ Non-drugged drivers $(n=22)$} & \multicolumn{2}{|c|}{$\begin{array}{c}\text { Total } \\
(n=38)\end{array}$} \\
\hline & $\mathbf{n}$ & $\%$ & $\mathbf{n}$ & $\%$ & $\mathbf{N}$ & $\%$ \\
\hline Head injuries & 7 & 43.75 & 3 & 13.63 & 10 & 26.32 \\
\hline Fracture Femur & 2 & 12.5 & 1 & 4.55 & 3 & 7.89 \\
\hline Fracture tibia \& fibula & 2 & 12.5 & 3 & 13.63 & 5 & 13.16 \\
\hline Fracture humerus /radius \& ulna & 2 & 12.5 & 3 & 13.63 & 5 & 13.16 \\
\hline Fracture ribs & 2 & 12.5 & 1 & 4.55 & 3 & 7.89 \\
\hline
\end{tabular}

Table (7): Details of marijuana smoking drivers and non-drugged drivers with ISS >15

\begin{tabular}{|c|c|c|c|c|}
\hline Group & Injuries & RTS & ISS & Outcome \\
\hline \multirow[t]{5}{*}{ Non-drugged drivers } & $\begin{array}{l}\text { 1-Sciatic nerve injury and retroperitoneal hematoma. } \\
\text { 2-Fracture acetabulum. } \\
\text { 3-Bruises }\end{array}$ & 6.904 & 19 & \\
\hline & $\begin{array}{l}\text { 1-Deprssed fracture, extra-Dural, sub-Dural hemorrhage and } \\
\text { black eye. } \\
\text { 2-Abrasions, contusion and contused wounds. }\end{array}$ & 3.5652 & 29 & Died \\
\hline & $\begin{array}{l}\text { 1-Extra-Dural hemorrhage and black eye. } \\
\text { 2-Bruises \& contused wound. }\end{array}$ & 5.0304 & 29 & \\
\hline & $\begin{array}{l}\text { 1-Amputation of parts of fingers. } \\
\text { 2-Cut wound. }\end{array}$ & 7.8408 & 20 & \\
\hline & $\begin{array}{l}\text { 1-Extra-Dural hemorrhage and black eye. } \\
\text { 2-Open fracture tibia. } \\
\text { 3-Abrasions, bruises and contused wound. }\end{array}$ & 4.2978 & 38 & \\
\hline \multirow[t]{9}{*}{$\begin{array}{c}\text { Marijuana } \\
\text { smokingdrivers }\end{array}$} & $\begin{array}{l}\text { 1-Fracture pelvis and pelvic hematoma. } \\
\text { 2-Cut wound. }\end{array}$ & 7.8408 & 20 & \\
\hline & $\begin{array}{l}\text { 1-Depressed comminuted Fracture and extra-Dural hemorrhage. } \\
\text { 2-Fracture radius open. } \\
\text { 3-Cut wound. }\end{array}$ & 6.904 & 38 & \\
\hline & $\begin{array}{l}\text { 1-Depressed fracture, extra-Dural, sub-Dural hemorrhage and } \\
\text { black eye } \\
\text { 2-Fracture ribs- open. } \\
\text { 3-Cut wound. }\end{array}$ & 5.0304 & 45 & Died \\
\hline & $\begin{array}{l}\text { 1-Depessed fracture and black eye. } \\
\text { 2-Contused wound. }\end{array}$ & 6.904 & 29 & \\
\hline & $\begin{array}{l}\text { 1-Fracture and extradural hemorrhage. } \\
\text { 2-Rupture spleen and intraperitoneal hemorrhage. } \\
\text { 3-Contusions. }\end{array}$ & 4.7396 & 42 & Died \\
\hline & $\begin{array}{l}\text { 1-Rupture spleen and intraperitoneal hemorrhage. } \\
\text { 2-Abrasions and cut wound on left leg. }\end{array}$ & 4.2978 & 20 & Died \\
\hline & $\begin{array}{l}\text { 1-Fissure fracture and extra-Dural hemorrhage. } \\
\text { 2-Fracture femur. } \\
\text { 3-Abrasions, bruises and contused wound on left foot. }\end{array}$ & 6.904 & 38 & Died \\
\hline & $\begin{array}{l}\text { 1-Depressed comminuted Fracture and extra-Dural hemorrhage. } \\
\text { 2-Fracture patella open. } \\
\text { 3-abrasion, bruises and contused wound on left leg. }\end{array}$ & 5.004 & 38 & \\
\hline & $\begin{array}{l}\text { 1- Depressed comminuted Fracture and extra-Dural hemorrhage. } \\
\text { 2-Abrasion, bruises and contused wound. }\end{array}$ & 6.904 & 29 & Died \\
\hline
\end{tabular}


Table (8): Causes of death in died marijuana smoking drivers and non-drugged drivers

\begin{tabular}{|c|c|c|}
\hline Group & Injuries & Cause of death \\
\hline \multirow[t]{2}{*}{$\begin{array}{l}\text { Non- } \\
\text { drugged } \\
\text { drivers }\end{array}$} & $\begin{array}{l}\text { 1-Deprssed fracture, extra-Dural, sub-Dural } \\
\text { hemorrhage and black eye. } \\
\text { 2-Abrasions, contusion and contused wounds. }\end{array}$ & Severe head injury \\
\hline & $\begin{array}{l}\text { 1-Fracture ribs. } \\
\text { 2-Abrasions, bruises and contused wound in left } \\
\text { hand. }\end{array}$ & $\begin{array}{l}\text { Multiple fracture ribs with flail chest and lung } \\
\text { injury }\end{array}$ \\
\hline \multirow[t]{6}{*}{$\begin{array}{l}\text { Marijuana } \\
\text { smoking } \\
\text { drivers }\end{array}$} & $\begin{array}{l}\text { 1-Depressed fracture, extra-Dural, sub-Dural } \\
\text { hemorrhage and black eye } \\
\text { 2-Fracture ribs- open. } \\
\text { 3-Cut wound. }\end{array}$ & $\begin{array}{l}\text { Severe head injury and multiple fracture ribs } \\
\text { with underlying injury to the lung and } \\
\text { heamopnuemothorax. }\end{array}$ \\
\hline & $\begin{array}{l}\text { 1-Fissure fracture and extra-Dural, hemorrhage. } \\
\text { 2-rupture spleen and intraperitoneal hemorrhage. } \\
\text { 3-contusions. }\end{array}$ & $\begin{array}{l}\text { Severe Head trauma and heamorrhagic shock } \\
\text { attributable to concomitant abdominal injury. }\end{array}$ \\
\hline & $\begin{array}{l}\text { 1-Fracture femur. } \\
\text { 2-Multiple bruises. }\end{array}$ & Heamorrhagic shock \\
\hline & $\begin{array}{l}\text { 1-Rupture spleen and intraperitoneal } \\
\text { hemorrhage. } \\
\text { 2-Abrasions and cut wound on left leg. }\end{array}$ & $\begin{array}{l}\text { Heamorrhagic shock attributable to concomitant } \\
\text { abdominal injury. }\end{array}$ \\
\hline & $\begin{array}{l}\text { 1-Fissure fracture and extradural hemorrhage. } \\
\text { 2-Fracture femur. } \\
3 \text {-Abrasions, bruises and contused wound on left } \\
\text { foot. }\end{array}$ & Severe Head trauma and hemorrhagic shock. \\
\hline & $\begin{array}{l}\text { 1-Depressed comminuted fracture and extra- } \\
\text { Dural hemorrhage. } \\
\text { 2-Fracture patella open. } \\
\text { 3-Abrasion, bruises and contused wound. }\end{array}$ & Severe head trauma and hemorrhagic shock. \\
\hline
\end{tabular}

Table (9): Kendall's tau b correlation of cannabis urine level with both ISS and RTS

\begin{tabular}{|c|c|c|c|c|}
\hline \multirow[t]{2}{*}{ Cannabis urine level (ng/ml) } & \multicolumn{2}{|c|}{ ISS } & \multicolumn{2}{|c|}{ RTS } \\
\hline & $\tau$ & $\mathbf{p}$ & $\tau$ & $\mathbf{p}$ \\
\hline Cannabis urine level (total 16) & & & & \\
\hline $\begin{array}{lc}\text { Minimum-Maximum } & 52-1418.12 \\
\text { Mean } \pm \text { Std. Deviation } & 502.35 \pm 464.31\end{array}$ & 0.207 & 0.275 & 0.152 & 0.445 \\
\hline
\end{tabular}

$\tau:$ Kendall's tau b correlation coefficient

Table (10): Mann-Whitney $U$ test for comparison of cannabis urine level in survived and died marijuana smoking drivers

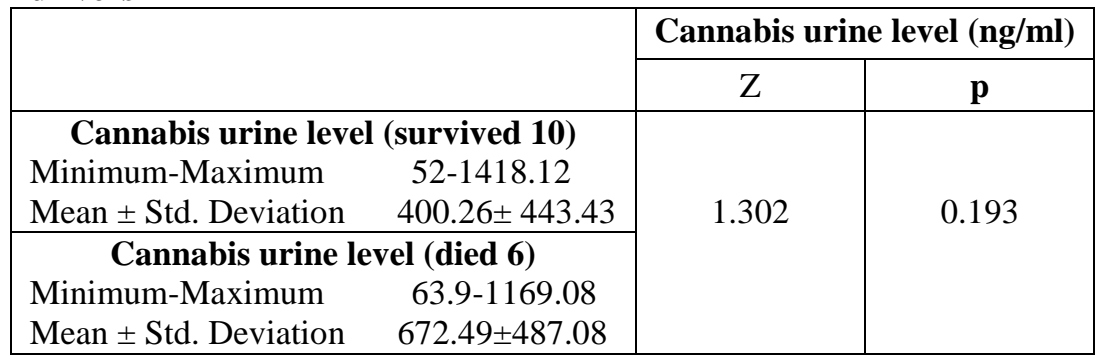

\section{Discussion}

In Egypt, epidemiological data on drug abuse are still very scarce. Very little reports can be gathered because drug abuse is prohibited by religious and legal systems (Emara, 1998). Most drivers believes that substance abuse relieves fatigue, makes the journey easier, and even prevents sleepiness, although sleep debt accumulates and cannot be relieved without normal restorative sleep (Lyznicki et al., 1998). Against a backdrop of clarity about dangers of driving under influence of drugs, questions have been rightfully raised in general community about impact of cannabis use on driving performance and risk of motor vehicle crashes. 
A recent review by the European Monitoring Centre for Drugs and Drug Addiction (EMCDDA,2008b) revealed that $0.3 \%-7.4 \%$ (3.9\% on average) of drivers tested positive for cannabis. This review included seven roadside surveys conducted between 1997 and 2007 in Australia, Denmark, the Netherlands, Norway, the United Kingdom, and the United States, using blood, urine or saliva tests. Hand in hand with this review, the results of the current study revealed that 53 drivers have arrived to Tanta University Emergency Hospital for road traffic injury. Out of them, sixteen drivers $(30.19 \%)$ registered cannabis in urine, fifteen drivers $(28.3 \%)$ registered multiple drugs and twenty two (41.51\%) were nondrugged drivers.

Such results could be explained in light of cannabis ability to induce performance degradation and increased risk of accident. Besides, it can produce risktaking behavior that can impair driving skills (Lane et al., 2005;Ramaekers et al., 2006). Furthermore, it causes impairments in hand-eye coordination, vigilance, time and distance perception, decision making, and concentration. Recent controlled laboratory research has suggested that cannabis impairs tasks of selective and divided attention, time estimation, and executive function (Kelly et al., 2004;Turner, 2007). Experimental studies have shown that cannabis has negative effects on cognitive functions and psychomotor skills. It is demonstrated that cannabis affects short-term memory, reaction time, ability to process information, maneuverability (tracking) and learning (Kurzthaler et al., 1999;Menetrey et al., 2005;Messinis et al., 2006).

However, several comparable accident records all over the world declared nothing certain about causal relationships between accidents and marijuana smoking (Asbridge et al., 2005;Laumon et al., 2005; Walsh et al., 2005;Christophersen, 2006). This may explain absence of significant statistical difference in both demographic and initial clinical data between marijuana smoking drivers and non-drugged drivers. Nevertheless, age of marijuana smoking drivers ranged from 18-40 years with prevalence of male gender (15 drivers who represented93.8\%) that coincide with Guo et al. (2002) who stated that illicit drug abuse is a youth phenomenon. Numerous Egyptian studies recorded more or less similar age and gender for prevalence of cannabis abuse in traumatized patients (Asaad et al., 2003; Abu El-Einen, 2004;Hamed, 2006; Abd El-Wahaab et al., 2009;Lashin, 2011).

Relating cannabis in particular, several researchers have surveyed the general driving population for cannabis abuse in both urine and blood (Compton \&Berning, 2009; Lacey et al., 2009 and EMCDDA, 2008b).Likewise, studies have examined the relationship between cannabis use and driving performance (Lane et al., 2005;Ramaekers et al., 2006;Turner, 2007). Different studies have shown significant proportion of road traffic crashes attributable to marijuana use while driving globally (Sharma, 2008 and Mir et al., 2012).
Yet, according to the best of available knowledge, none of these researches have discussed severity of injuries in marijuana smoking drivers. Furthermore, association between severity of injuries and marijuana level was not established in previous investigates. In the current study, there was no statistical significant difference in the spectrum of injuries (distribution and type) among different body parts between both non-drugged drivers and marijuana smoking drivers. This could be attributed to being seated in identical seat. Subsequently, the mechanism of injury is unchanged in both non-drugged drivers and marijuana smoking drivers.

Fractures of skull associated with intracranial injury were detected in $17.93 \%$ of total road traffic injured patients (both drugged and non-drugged) according to Pan et al. (2014). In the present study, they were recorded in $43.75 \%$ of marijuana smoking drivers and in $13.63 \%$ of non-drugged drivers. Such variable incidence might be due to seat belt use and air bagequipped cars (Martin et al., 2000). As recorded by Pan et al. (2014), fracture of upper limb registered $12.22 \%$ of total road traffic injured patients which coincide with the current study. Where, $12.5 \%$ of marijuana smoking drivers and $13.63 \%$ of non-drugged drivers have shown upper limb fracture.

Fracture femur has occurred in two marijuana smoking drivers $(12.5 \%)$ and one non-drugged driver $(4.55 \%)$. Whereas, femoral shaft fracture incidence from road traffic collisions in low and middle income countries was between 15.7 and 45.5 per 100,000 people per year according to Agarwal-Harding et al. (2015). Both soft tissue injury and bony fractures are expressed in injury severity score (ISS).

Both Injury Severity Score (ISS) and Revised Trauma Score (RTS) exhibited statistical significant difference between non-drugged drivers and marijuana smoking drivers. Together, (ISS) and (RTS) represent anatomical injury and physiological response to injury respectively. The later includes Glasgow Coma Scale, systolic blood pressure and respiratory rate. Here, as a result of short or long-term ingestion of cannabis, individuals may experience changes in physiological functioning (Atkinson et al., 2009).

Consequently, mortality revealed statistical significant difference between non-drugged drivers and marijuana smoking drivers. Even though (ISS) has been reported to influence mortality of trauma patients, head trauma and age has also been shown to affect mortality rates in these patients (Hill et al., 1996; Hui et al., 2002).

In the present study, two $(9.09 \%)$ non-drugged drivers have died due to severe head injury (ISS $=29$ ) and multiple fracture ribs with flail chest together with lung injury (ISS = 13). This difference in expected and observed mortality may be attributed to the quality of trauma care in hospital settings. It also reflects the quality of prehospital care including time to definitive care. In the same way, one $(6.25 \%)$ of the marijuana smoking 
drivers has died from hemorrhagic shock due to fracture femur (ISS = 10).

In marijuana smoking drivers, hemorrhagic shock was the most common cause of death. It might be induced by rupture spleen (ISS $=42,20$ ), fracture femur (ISS $=38$ ) and head injury (ISS $=29$ ). Severe head injury with multiple fracture ribs, underlying lung injury and heamopnuemothorax were the cause of death in one $(6.25 \%$ ) marijuana smoking driver (ISS $=45$ ). Four (25\%) marijuana smoking drivers have registered severe ISS = 20, 38, 29 and 38, however, they did not die. These survivals might be attributed to prompt diagnosis, early involvement of senior members of medical staff in their care, and being able to utilize on-site diagnostic imaging facilities, thus avoiding unnecessary transfers.

There was no significant correlation between urine cannabis level and both ISS and RTS. Additionally, there was no significant difference in urine cannabis level between died and survived patients. Absent correlation could be clarified on account of analyzing drivers' urine samples, which contain only inactive THC metabolite that does not necessarily indicate recent cannabis use (Ramaekers et al., 2004). Featuring blood samples that detect active THC metabolites, in further future researches might reveal more accurate idea about such correlation.

A major limitation of the current study was cannabis detection in urine and limited sample size. Therefore, future comparable researches are required with detection of accurate cannabis blood level. Moreover, larger scale of registration of road traffic injury victims in multiple emergency hospitals all over the country will record more accurate and representative data. Such data will help both prevention and better management of marijuana smoking drivers, with subsequent decrease in morbidity and mortality.

\section{Conclusion}

From the current study, it could be concluded that, marijuana smoking is a common public health problem. As a result of short or long-term ingestion of cannabis, individuals might experience changes in physiological functioning which have led to elevated ISS and RTS. Consequently, death induced by injuries has occurred in marijuana smoking drivers more than non-drugged drivers.

\section{Recommendations}

Overall public health education about adverse effects of short and long term cannabis abuse, especially, producing risk-taking behavior that can impair driving skills, to prevent and reduce road accidents.

Continuous and period checkup and drug monitoring should be a must to acquire or recommence driving license to exclude cannabis abusers to avoid unsafe driving that may take place with cannabis abusers.

Motor car accident patients should be routinely screened for cannabis in Emergency departments and, if they are found positive, interventions should be initiated as identification and referral of these patients to treatment programs, providing an opportunity to help them to develop insight into the consequences of their abuse to decrease the risk of repeated accidents and decrease burden on the workload and financial resources of the hospital.

\section{References}

Abbas KA (2004): Traffic Safety Assessment and Development of Predictive Models for Accidents on Rural Roads in Egypt. Accid. Anal. Prev. 61 (3): 149-163.

Abd El-Wahaab AD, Shehata MM, Abdel-Hady RH, et al., (2009): Risk factors lead to Bango abuse among drivers and secondery school students in Assiut province. Iranian J. of Toxicology. 2(4):246-53.

Abu El-Einen RG (2004): Prevalence, screening and assessment of psychoactive substance use among patients presenting to toxicology unit in Mansoura Emergency Hospital. M.D. thesis in Forensic Medicine and Clinical Toxicology, Faculty of Medicine, Mansoura University: 155172.

Agarwal-Harding KJ, Meara JG, Greenberg SLM, et al. (2015): Estimating the Global Incidence of Femoral Fracture from Road Traffic Collisions. The Journal of Bone and Joint Surgery, 97: e31, $1-9$.

Andrews R, Murphy K J, Nahar L, et al. (2015): Cannabinoid Concentrations Detected in Fatal Road Traffic Collision Victims Compared with a Population of Other Postmortem Cases. Clinical Chemistry (61):10 1256-1264

Arterberry BJ, Treloar HR, Smith AE, et al. (2012): Marijuana use, driving, and related cognitions. Psychology of Addictive Behaviors, 27 (3), 854860.

Asaad TAA, Okasha TA and EL -Khouly GA (2003): Substance abuse in a sample of Egyptian schizophrenic patients. Addictive Disorders and Their Treatment; 2 (4):147-150.

Asbridge M, Hayden JA, Cartwright JL (2012): Acute cannabis consumption and motor vehicle collision risk: Systematic review of observational studies and meta-analysis. British Medical Journal,9; 344:e536.

Asbridge M, Poulin C, Donato A (2005): Motor vehicle collision risk and driving under the Influence of Cannabis: evidence from adolescents in Atlantic Canada. Accid Anal Prev, 37: 1025-1034.

Ashton CH (1999): Adverse effects of cannabis and cannabinoids. Br J Anaesth, 83: 637-49.

Atkinson A, Anderson Z, Hughes K, et al. (2009): Interpersonal violence and illicit drugs. Centre for Public Health. Liverpool, John Moores University. www.cph.org.uk.

Christophersen AS. (2006): The risk posed by drugs in traffic. Transportation Research e-circular, EC096 0097 - 8515. Drugs in Traffic in 2006; 57 62. 
Compton R and Berning A (2009): Results of the 2007 national roadside survey of alcohol and drug use by drivers. Washington, DC: National Highway Traffic Safety Administration: 473-85.

Drummer OH, Kourtis I, Beyer J, et al. (2012): The prevalence of drugs in injured drivers. Forensic SciInt, 215:14-7.

Emara AM (1998): Toxicological, biochemical, psychological study on patients with drug abuse. M.D. Thesis of Clinical Toxicology, Faculty of Medicine, Tanta University: 12-40.

EMCDDA (2008b): Drug use, impaired driving and traffic accidents. EMCDDA Insights Series No 8. Luxembourg: Office for Official Publications of the European Communities: 813- 34.

Field A, ed. (2006): Discovering Statistics Using SPSS. 2nd ed. London, California, New Delhi: SAGE Publications Ltd.

Guo J, Hill KG and Hawkins JD (2002): A developmental analysis of sociodemographic, family and peer effects on adolescent illicit drug initiation. J. Am. Acad. Child. Adol. Psychi. 41(7): 838-845.

Hamed RHA (2006): Toxicological screening of trauma patients in urban and rural areas. M.D. Thesis of Forensic Medicine and Clinical Toxicology, Faculty of Medicine, Mansoura University: 110122.

Hartman RL and Huestis MA (2013): Cannabis effects on driving skills. ClinChem, 59:478-92.

Hill DA, Delaney LM and Duflou JA (1996): population-based study of outcome after injury to car occupants and to pedestrians. J Trauma 1996; 40:351-5.

Hui T, Avital I, Soukiasian H, et al. (2002) : Intensive care unit outcome of vehicle- related injury in elderly trauma patients. Am Surg, 68:1111-14.

Joseph S and Ronald CB (2006): Focus on urine drug monitoring: Are your patients compliant, diverting, or supplementing the drugs that are prescribed for their chronic pain?. Practical Pain Management: 60-67.

Kelly E, Darke S and Ross J (2004): A review of drug use and driving: Epidemiology, impairment, risk factor and risk perceptions. Drug and Alcohol Review 23, 319-344.

Kurzthaler I, lobster M, Miller C, et al. (1999) : Effect of cannabis use on cognitive functions and driving portability. J Clin Psychiatry, 60: 395-9.

Lacey JH, Kelley-Baker T, Furr-Holden D, et al. (2009): 2007 National road-side survey of alcohol and drug use by drivers: drug results. Washington (DC): National Highway Traffic Safety Administration. Office of Behavioral Safety Research: 1255-70.

Lane SD, Cherek DR, Tcheremissine OV, et al. (2005): Acute marijuana effects on human risk taking. Neuro psycho pharmacology, 30: 800-9.
Lashin H (2011): Prevalence of cannabis use among injured patients admitted to Tanta University Emergency Hospital. M.D. Thesis of Forensic Medicine and Clinical Toxicology, Faculty of Medicine, Tanta University: 122-140.

Laumon B, Gadegbeku B, Martin JL, et al. (2005) :Cannabis intoxication and fatal road crashes in France: population based case-control study. BMJ, 331: 1371.

Li MC, Brady J E, DiMaggio C J, et al. (2012): Marijuana use and motor vehicle crashes. Epidemiologic Reviews, 34(1), 65-72.

Lyznicki JM, Doege TC, Davis RM, et al. (1998): Sleepiness, driving, and motor vehicle crashes. JAMA, 279(23):1908.

Martin PG, Crandall JR, Pilkey WD (2000):Injury trends of passenger car drivers in frontal crashes in the USA.Accident Analysis and Prevention 32: 541-557.

Menetrey A, Augsburger M, Favrat B, et al. (2005): Assessment of driving capability through the use of clinical and psychomotor tests in relation two blood cannabinoids levels following Constantly oral administration of 20 mg dronabinol or of a cannabis decoction made with 20 or $60 \mathrm{mg}$ Delta9-THC. J Anal Toxicol, 29: 327-38.

Messinis L, Kyprianidou A, Malefaki S, et al. (2006): Neuropsychological deficits in longterm frequent cannabis users. Neurology, 66: 737-9.

Mir MU, Khan I, Ahmed B, et al. (2012): Alcohol and marijuana use while driving-an unexpected crash risk in Pakistani commercial drivers: a cross-sectional survey. BMC Public Health, 12:145-151.

Nayeem N, Kotecha MB, Baritrop AH (1992): Care of road traffic accident victims in a district general hospital Annals of the Royal College of Surgeons of England, 74: 212-217.

Obada S. (2009): Traffic Problems in Egypt and Emirates. Comparative study. Police Academy, Cairo. 12-19.

Pan RH, Chang NT, Chu D, et al. (2014): Epidemiology of Orthopedic Fractures and Other Injuries among Inpatients Admitted due to Traffic Accidents: A 10-Year Nationwide Survey in Taiwan. Scientific World Journal, 2014, ID $637872,7$.

Ramaekers JG, Berghaus G, vanLaar M, et al. (2004): Dose related risk of motor vehicle crashes after cannabis use. Drug and Alcohol Dependence 73, 109-119.

Ramaekers JG, Kauert G, Van Ruitenbeek P, et al. (2006): High- potency marijuana impairs executive function and inhibitory motor control. Neuro psycho pharmacology; 31:2296-303.

Ronen A, Gershon P, Drobiner H, et al. (2008): Effects of THC on driving performance, physiological 
state and subjective feelings relative to alcohol. Accid Anal Prev; 40:926-34.

Sharma BR (2008): Road traffic injuries: a major global public health crisis. Public Health, 122 (12): 1399-1406.

Swift W, Jones C, Donnelly N (2010): Cannabis use while driving: A descriptive study of Australian cannabis users. Drugs: Education, Prevention, and Policy, 17(5): 573-586.

Turner BMA (2007): Sex, drugs, and driving: The effects of marijuana. Turner, Beth Marie Anderson: U Iowa, US.
Van Natta TL and Morris JA Jr (2000): Injury scoring and trauma outcomes. In: Mattox KL, Feliciano DV, Moore EE, eds. Trauma, 4th edn. New York NY: McGraw-Hill, 2000:69-80.

Walsh JM, Flegel R, R Atkins, et al. (2005) :Drug and alcohol use Among drivers admitted to a level-1 trauma center. Accid Anal Prev, 37: 894-901.

Zavala SK and French MT (2003): Dangerous to Your Health: The Role of Chronic Drug Use in Serious Injuries and Trauma. Medical Care. 41(2):309-322.

\section{الأملخص العربيى}

\section{تقييم سمي وطبي شرعي لأنماط الإصابة والوفيات في السائقين المدخنين للقنب والسائقين غير المتعاطين دراسة مقارنة}

\section{مروة محمد شاهين و أروة أحمد أبو الفضل}

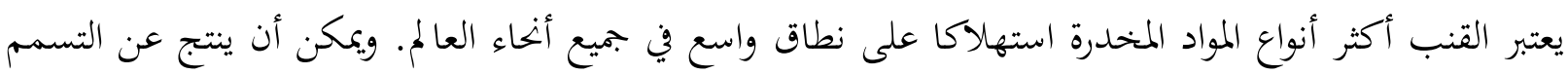
الحاد بالقنب ضعف في مهارات القيادة. وتعد القيادة تحت تأثير القنب مصدر قلق عالمي على الصحة العامة بشكل متزايد.

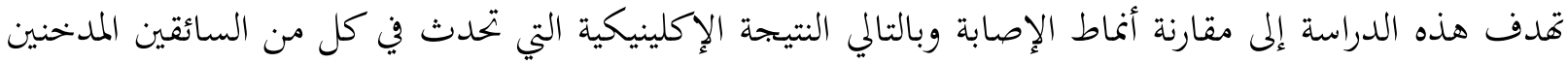
للقنب والسائقين غير المتعاطين بين ضحايا حوادث السيارات بمستشفى الطوارئ جامعة طنطا.

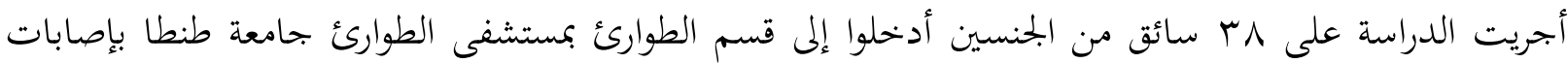

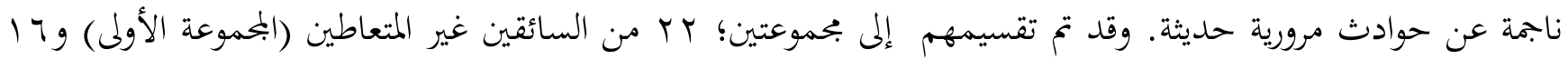

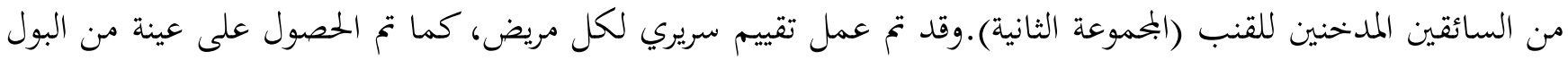

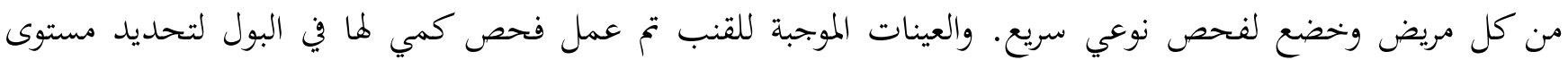
القنب في البول.

وكشفت نتائج الدراسة الحالية عن وجود فروق ذات دلالة إحصائية بين السائقين المدخنين للقنب والسائقين غير

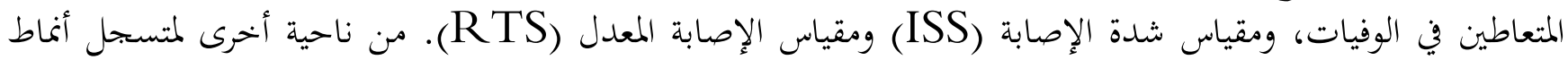

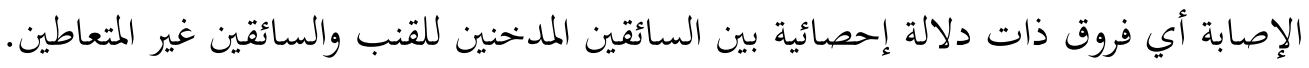

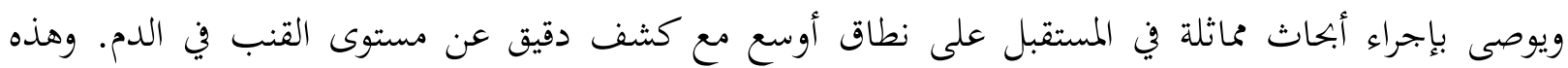

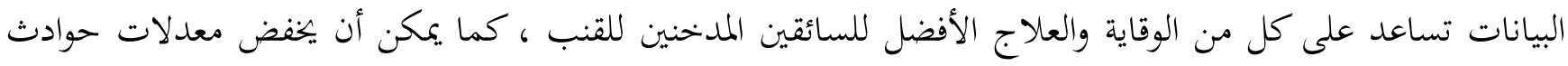
الطرق وبالتالي تقليل نسبة الإصابة والوفيات. 